\title{
DESAIN PERKULIAHAN BAHASA ARAB MELALUI GOOGLE CLASSROOM
}

\author{
Abd. Rozak, Azkia Muharom Albantani \\ Universitas Islam Negeri Syarif Hidayatullah Jakarta, Indonesia \\ rozak@uinjk.t.ac.id
}

\begin{abstract}
In this modern day, the number of different ways of learning in addition to being in the classroom, one of them is learning through Google Classroom. This type of research was a qualitative research in the form of field research. Arabic lectures were conducted by using Google Classroom media and administrated by six different classes in non-language study program environments. This study showed that this application can help and facilitate the lecturers and students in carrying out the learning process in depth. This was because both students and lecturers can collect the assignments, distribute the assignments, and assess the assignments at home or anywhere without being bound by time limits or hours of study.
\end{abstract}

Keywords: $\quad$ google classroom, Arabic lecture, lecture design

\section{Abstrak}

Di zaman modern sekarang ini terdapat macam-macam cara dalam pembelajaran selain berada diruangan kelas, salah satunya adalah pembelajaran melalui Google Classroom. Jenis penelitian ini merupakan penelitian kualitatif dalam bentuk penelitian lapangan. Perkuliahan bahasa Arab dilakukan menggunakan media Google Classroom oleh 6 (enam) kelas berbeda di lingkungan program studi non-bahasa. Penelitian ini menunjukkan bahwa aplikasi ini dapat membantu memudahkan dosen dan mahasiswa dalam melaksanakan proses belajar dengan lebih mendalam. Hal ini disebabkan karena baik mahasiswa maupun dosen dapat mengumpulkan tugas, mendistribusikan tugas, menilai tugas di rumah atau dimanapun tanpa terikat batas waktu atau jam pelajaran.

Kata Kunci: $\quad$ google classroom, perkuliahan bahasa Arab, desain perkuliahan 
Ara6iyât Jurnal Pendidikan Bahasa Arab dan Kebahasaaraban, 5 (1), 2018

\section{Pendahuluan}

Bahasa Arab merupakan media komunikasi di berbagai dunia yang telah berkembang pesat dalam sosial masyarakat dan mengaplikasikannya dalam ilmu pengetahuan. Untuk mempermudah komunikasi dengan menggunakan bahasa arab diperlukan juga media lain agar membantu terlaksananya komunikasi Bahasa Arab seperti tekhnologi. Sesungguhnya, penggunaan tekhnologi dalam proses pembelajaran memberi kesempatan dan peluang bagi tenaga pengajar dalam hal ini guru untuk dapat meningkatkan dan mengembangkan kompetensinya terutama kompetensi profesional. Penggunaan teknologi dalam permasalahan pembelajaran di kelas diharapkan mampu memberi solusi dalam mengatasi pembelajaran di kelas yang disebabkan oleh kurang optimalnya peran guru dalam memanfaatkan teknologi dalam dunia pendidikan. Salah satu hal yang bisa dimanfaatkan oleh dunia pendidikan terutama guru dalam kegiatan pembelajaran bahasa Arab ini adalah pemanfaatan aplikasi Google Classroom. Aplikasi ini masih jarang bahkan belum diketahui oleh sebagian besar para pendidik di Indonesia. Layanan ini diasumsikan menjadi salah satu layanan dalam menjawab pesoalan dan tantangan di Kelas. Seperti terbatasnya waktu yang terdapat di kelas untuk berdiskusi dan mengkaji suatu tugas atau materi khususnya bahasa Arab ini. ${ }^{1}$

Sebuah penelitian yang dilakukan oleh Abdul Barir Hakim menunjukkan bahwa penggunaan sistem e-learning (E-Learning Moodle, Google Classroom, dan Edmodo) dapat membangkitkan minat dan motivasi. ${ }^{2}$ Pradana menjelaskan juga bahwa kelas yang menggunakan Tools Google Classroom pada model pembelajaran Project Based Learning memiliki nilai rata-rata yang baik. ${ }^{3}$ Lebih lanjut Rahmat Iswanto dalam penelitiannya menjelaskan bahwa Arabic E-learning memungkinkan tersampaikannya bahan ajar ke peserta didik dengan menggunakan media internet, intranet atau media jaringan komputer lain. Teknologi dapat meningkatkan kemampuan atau kompetensi pengajar dalam mengajar bahasa Arab, mampu memanfaatkan alokasi waktu untuk pembelajaran bahasa Arab, dan mampu menciptakan lingkungan berbahasa Arab. ${ }^{4}$ Selain itu, Mahyudin Ritonga dkk dalam penelitian menunjukkan bahwa teknologi dapat dipandang sebagai media pembelajaran bahasa Arab, karena dapat dijadikan sebagai fasilitas pembelajaran yang dapat membantu peserta didik untuk lebih mudah

${ }^{1}$ Vicky Dwi Wicaksono dan Putri Rachmadyanti, "Pembelajaran Blended Learning Melalui Google Classroom di Sekolah Dasar", Prosiding Seminar Nasional Pendidikan PGSD UMS \& HDPGSDI Wilayah Jawa, 2017, 513-521. Lihat juga Arief S. Sadiman, dkk, Media Pendidikan: Pengertian, Pengembangan, dan Pemanfaatannya,(Depok: Rajawali Pers, 2012), 17-19.

2 Abdul Barir Hakim, "Efektifitas Penggunaan E-Learning Moodle, Google Classroom dan Edmodo", I-STATEMENT, Volume 2 Nomor 1, Januari 2016, 1-6.

${ }^{3}$ Diemas Bagas Panca Pradana. Rina Harimurti. "Pengaruh Penerapan Tools Google Classroom pada Model Pembelajaran Project Based Learning terhadap Hasil Belajar Siswa", Jurnal IT-Edu, Volume 02 Nomor 01 Tahun 2017, 59-67. Lihat juga Dicky Pratama \& Hendri Sopryadi, "Analisis Pengaruh Pemanfaatan Google Classroom terhadap Efisiensi pada STMIK XYZ", Seminar Nasional Teknologi Informasi 2016, 49-52.

${ }^{4}$ Rahmat Iswanto, "Pembelajaran Bahasa Arab dengan Pemanfaatan Teknologi", Arabiyatuna: Jurnal Bahasa Arab, Vol. 1, No. 2, 2017, 139-152. Lihat juga Azkia Muharom Albantani \& Ahmad Madkur, "Musyabadat Al Fidyu: Youtube-Based Teaching and Learning of Arabic As Foreign Language (AFL)", DINAMIKA ILMU, Vol. 17 No. 2, 2017, 291-308. 
memahami bahasa Arab dan juga dapat meningkatkan motivasi peserta didik untuk lebih giat dalam mempelajari bahasa Arab. ${ }^{5}$ Sedangkan tulisan ini mencoba untuk mengungkap desain perkuliahan bahasa Arab dengan menggunakan google classroom.

\section{Metode}

Penelitian ini merupakan penelitian kualitatif dalam bentuk penelitian lapangan. Perkuliahan bahasa Arab dilakukan menggunakan media google classroom oleh 6 (enam) kelas berbeda di lingkungan program studi non-bahasa Fakultas Ilmu Tarbiyah UIN Syarif Hidayatullah Jakarta dengan lama belajar sebanyak 14 kali pertemuan. Setiap pertemuan membutuhkan waktu pembelajaran selama 2 jam 30 menit. Setiap kelas dibagi ke dalam 10 (sepuluh) kelompok beranggotakan masing-masing 3-4 mahasiswa. Jumlah anggota kelompok 1-5 lebih sedikit dibanding kelompok 6-10 mengingat tingkat kesulitan materi yang tersedia di dalam buku. Perkuliahan bahasa Arab untuk program studi non-bahasa bertujuan supaya mahasiswa memahami kosakata bahasa Arab dan kaidah bahasa Arab sederhana. Adapun materi perkuliahan berorientasi kepada penguasaan general Arabic (Bahasa Arab Dasar).

\section{Selayang Pandang Google Classroom}

Google classroom sesungguhnya dirancang untuk mempermudah interaksi dosen atau guru dengan mahasiswa atau siswa dalam dunia maya. Aplikasi ini memberikan kesempatan kepada para dosen atau guru untuk mengeksplorasi gagasan keilmuan yang dimilikinya kepada mahasiswa atau siswa. Dosen memliki keleluasaan waktu untuk membagikan kajian keilmuan dan memberikan tugas mandiri kepada mahasiswa. Selain itu, dosen juga dapat membuka ruang diskusi bagi para mahasiswa atau siswa secara online. Namun demikian, terdapat syarat mutlak dalam mengaplikasikan google classroom yaitu membutuhkan akses internet yang mumpuni. Aplikasi ini dapat digunakan oleh siapa saja yang tergabung dengan kelas tersebut. Kelas tersebut adalah kelas yang didesain oleh dosen yang sesuai dengan kelas sesungguhnya atau kelas nyata di dalam perkuliahan. Terkait dengan anggota kelas google classroom Herman (2014) menjelaskan bahwa aplikasi ini menggunakan kelas tersedia bagi siapa saja yang memiliki Google Apps for Education, serangkaian alat produktivitas gratis termasuk gmail, dokumen, dan drive. ${ }^{6}$

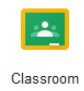

Gambar 1. Ikon Aplikasi Google Classroom

\footnotetext{
${ }^{5}$ Mahyudin Ritonga, Alwis Nazir, Sri Wahyuni, "Pembelajaran Bahasa Arab Berbasis Teknologi Informasi dan Komunikasi di Kota Padang", Arabiyât : Jurnal Pendidikan Babasa Arab dan Kebahasaaraban, 3, (1), 2016, 1-12.

${ }^{6}$ Heather Garczynski, "Tech Tools for Teachers, by Teachers: Google is at it Again! Google Classroom Changes the Face of Education”, Wisconsin English Journal, Vol. 56, No. 2, 2014, 32-36.
} 
Arabiyât Jurnal Pendidikan Bahasa Arab dan Kebahasaaraban, 5 (1), 2018

Rancangan kelas yang mengaplikasikan google classroom sesungguhnya ramah lingkungan. Hal ini dikarenakan mahasiswa tidak menggunakan kertas dalam mengumpulkan tugasnya. Hal ini sejalan dengan pendapat Herman yang memaparkan bahwa dalam aplikasi ini, kelas dirancang untuk membantu dosen membuat dan mengumpulkan tugas tanpa kertas, termasuk fitur yang menghemat waktu seperti kemampuan untuk membuat salinan google document secara otomatis bagi setiap mahasiswa. Kelas juga dapat membuat folder drive untuk setiap tugas dan setiap mahasiswa, agar semuanya tetap teratur.

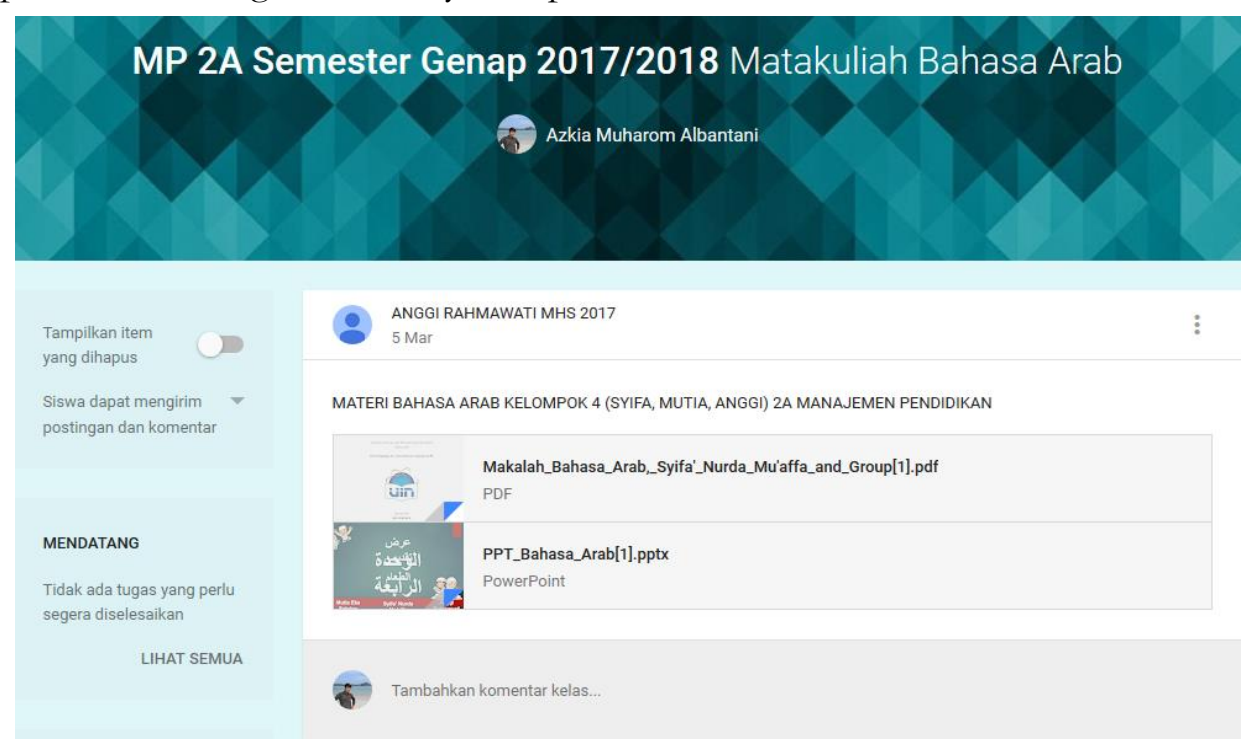

Gambar 2. Halaman Utama di Google Classroom

Selain tugas, dosen juga dapat melemparkan sebuah gagasan berupa ide kekinian untuk didiskusikan di dalam kelas google classroom dan jika dalam pembelajaran di kelas nyata (di sekolah) terdapat pembahasan materi yang belum terselesaikan, (melalui video) maka dapat diselesaikan dan dilanjutkan pada forum diskusi google classroom.

Google Classroom merupakan sebuah aplikasi yang diciptakan oleh Google yang memungkinkan terciptanya ruang kelas di dunia maya. Selain itu, aplikasi ini menjadi sarana dikumpulkannya tugas-tugas. ${ }^{7}$ Aplikasi ini sangat memudahkan proses pembelajaran oleh dosen dan mahasiswa dalam melaksanakan proses belajar. Google classroom sesungguhnya dirancang untuk mempermudah interaksi dosen dan mahasiswa dalam dunia maya. Aplikasi ini memberikan kesempatan kepada para dosen untuk mengeksplorasi gagasan keilmuan yang dimilikinya kepada mahasiswa. Dosen memiliki keleluasaan waktu untuk membagikan kajian keilmuan dan memberikan tugas mandiri kepada siswa. selain itu, dosen juga dapat membuka ruang diskusi bagi para mahasiswa

7 Noordin Asnawi, "Pengukuran Usability Aplikasi Google Classroom Sebagai E-learning Menggunakan USE Questionnaire (Studi Kasus: Prodi Sistem Informasi UNIPMA)", Research : Journal of Computer, information system, \& technology management, Vol. 1, No. 2, 2018, 17-21. 
secara online. Namun demikian, ada syarat mutlak dalam mengaplikasikan google classroom, yaitu membutuhkan akses internet yang mumpuni.

Mahasiswa dapat melacak setiap tugas yang hampir mendekati batas waktu pengumpulan di laman Tugas, dan mulai mengerjakannya cukup dengan sekali klik. Dosen dapat melihat dengan cepat siapa saja yang belum menyelesaikan tugas, serta memberikan masukan dan nilai langsung di kelas.

Pesatnya perkembangan Teknologi Informasi dan Komunikasi khususnya internet dan google classroom memungkinkan bahkan sangat mungkin mengembangkan layanan informasi yang lebih baik dalam suatu institusi pendidikan. Di lingkungan perguruan tinggi, misalnya pemanfaatan TIK lainnya yaitu diwujudkan dengan suatu sistem yang disebut electronic university (e-university). Pengembangan e-university bertujuan untuk mendukung penyelenggaraan pendidikan, sehingga perguruan tinggi dapat memberi pelayanan informasi yang baik kepada komunitasnya. ${ }^{8}$ Sama halnya dengan penggunaan google classroom di kalangan pendidik di Indonesia, yakni yang bertujuan untuk mempermudah akses pembelajaran. Dengan jadwal dosen yang dapat dan kadang tidak memungkinkan untuk hadir di kelas, maka google classroom membantu memaparkan materi yang akan disampaikan oleh dosen melalui teks atau materi yang telah diupload di google classroom. Pembelajaran seperti ini mungkin bisa disebut sebagai pembelajaran daring atau kuliah daring karena materi kuliah bisa diakses oleh siapa saja yang membutuhkan, di manapun dan kapanpun. Hal ini dapat memudahkan informasi bagi siapapun yang kesulitan informasi karena masalah ruang dan waktu.

Pengembangan dan penerapan google classroom juga bermanfaat untuk peningkatan kualitas pendidikan Indonesia. Salah satu aspeknya adalah kondisi geografis Indonesia dengan sekian banyaknya pulau yang tersebar di Indonesia dan dengan kontur permukaan bumi yang sering tidak bersahabat, biasanya diajukan untuk menjagokan dan mengembangkan teknologi salah satunya google classroom yang sangat mampu untuk menjadi fasilitator utama untuk meratakan pendidikan di bumi Nusantara sebab aplikasi ini juga mengandalkan kemampuan pembelajaran jarak jauh yang tidak terpisah oleh ruang, jarak, dan waktu.

Kerjasama antarpakar dan mahasiswa yang lokasinya saling berjauhan secara fisik dapat dilakukan dengan mudah. Dahulu, seseorang harus berkelana atau menempuh jarak, ruang dan waktu untuk menemui seorang pakar untuk mendiskusikan sebuah masalah. Saat ini, hal tersebut bisa dilakukan dari rumah dengan mengirimkan e-mail. Makalah dan penelitian juga dapat dilakukan dengan saling tukar menukar data lewat internet. Hal ini juga terjadi pada pemakaian google classroom, yakni materi ataupun bahan ajar terlebih dahulu diunggah lewat aplikasi ini oleh pemateri. Mahasiswa yang lain diwajibkan untuk mengunduh atau mempelajari materi yang telah diunggah di google classroom tersebut, sehingga batasan geografis bukan menjadi masalah lagi.

Google classroom memadukan google dokumen, drive dan gmail untuk membantu para pengajar dalam menciptakan kelas maya yang lebih cepat, efisien dan

\footnotetext{
${ }^{8}$ Deni Darmawan, Teknologi Pembelajaran, (Bandung: PT Remaja Rosdakarya, 2012), 5.
} 
sebagai alat berkomunikasi yang mudah. Google classroom membantu para mahasiswa belajar dan mengerjakan tugas tanpa harus membuang banyak kertas. Pembelajaran berbasis google classroom ini juga memudahkan untuk para pengajarnya membuat atau mengumumkan info dengan cepat dan menyeluruh kepada setiap mahasiswa.

Google classroom adalah sebuah aplikasi yang memungkinkan terciptanya ruang kelas di dunia maya. Lebih detailnya, aplikasi ini bisa menjadi sarana distribusi tugas, submit tugas bahkan menilai tugas-tugas yang dikumpulkan. Untuk distribusi tugas, tidak perlu khawatir akan adanya penyalahgunaan yang dilakukan mahasiswa, karena aplikasi ini memberikan hak akses bagi para dosen untuk mengatur tugas yang dipublikasi, sehingga mahasiswa bisa sekadar untuk melihat, mengedit bahkan berkolaborasi. Melalui google classroom juga, para dosen bisa memantau perkembangan belajar mahasiswa. Selain itu, google classroom menyediakan fitur forum diskusi. Para dosen bisa membuka sebuah diskusi kelas yang asyik untuk ditanggapi dan dikomentari. Kehadiran aplikasi ini bukan tidak mungkin dapat menggantikan peran kertas dan papan tulis, sehingga membuat proses belajar mengajar menjadi murah dan cepat. Bahkan tidak mustahil bila aplikasi ini menggantikan kelas formal di ruangan kelas yang sebenarnya di masa depan. Dalam penggunaannya para guru menilai google classroom tidak memiliki kendala apapun, terlebih lagi aplikasi ini telah didukung 42 bahasa.'

Google classroom sebagai salah satu media pembelajaran bahasa Arab bertujuan untuk memfasilitasi belajar dan memperbaiki kinerja. Dalam hal ini google classroom juga sebagai sumber belajar yang mendukung belajar termasuk sistem penunjang, materi, dan lingkungan pembelajaran. Aplikasi ini dapat menjadi alternatif sebagai salah satu sumber belajar bahasa Arab karena setiap materi yang akan dipresentasikan oleh suatu kelompok diunggah lewat google classroom. Sebelum memulai pelajaran, para mahasiswa mengunduh materi yang akan dipelajari.

Google Classroom merupakan sebuah fitur yang dimiliki oleh Google. Aplikasi ini menawarkan kegiatan belajar mengajar seperti layaknya di kelas. Aplikasi ini dapat memperkaya kita terhadap aplikasi-aplikasi lain yang terdapat di smartphone. Tidak dipungkiri lagi bahwa di generasi sekarang yang serba canggih, sedikit sekali individu yang tidak mengerti mengenai teknologi karena hal tersebut telah menjadi "kebutuhan pokok" di generasi ini. Hal ini yang membuat mahasiswa merasa tertarik sekaligus bangga dalam pemakaian aplikasi tersebut, karena tidak semua kelas atau mata kuliah di UIN Syarif Hidayatullah Jakarta yang mengaplikasikan Google Classroom sebagai dukungan media pembelajaran dengan memakai kontribusi dari teknologi yang dimiliki oleh Google. Sebelumnya, aplikasi ini sudah dipakai di dunia Barat sebagai penunjang pembelajaran terhadap kemajuan teknologi saat ini.

${ }^{9}$ Fransiskus Ivan Gunawan dan Stefani Geima Sunarman, "Pengembangan Kelas Virtual dengan Google Classroom dalam Keterampilan Pemecahan Masalah (Problem Solving) Topik Vektor Pada Siswa SMK untuk Mendukung Pembelajaran”, Prosiding Seminar Nasional Etnomatnesia, 2018, 340-348. Lihat juga Widya Herma, "Google Classroom Ruang Kelas Dunia Maya", http:// widjaherma.com diakses pada 27 April 2017 Pukul 12.30 WIB 
Dalam praktik penggunaannya, google classroom sangat mudah untuk digunakan kedalam kegiatan pembelajaran. Kita dapat mengunduh aplikasi ini secara cuma-cuma diperangkat smartphone berbasis android ataupun iOS. Namun untuk para pemula yang akan menggunakan aplikasi ini sebaiknya mendengar penjelasan atau tutorial dalam menggunakan aplikasi agar jelas dan untuk menghindari kebingungan dalam menggunakannya. Selain itu, pengguna juga harus terus memutakhirkan pengetahuan tentang fitur google classroom karena aplikasi ini akan terus ter-upgrade sesuai dengan waktu dan kita tidak boleh ketinggalan informasi tersebut.

Aplikasi ini memberikan fitur seperti Home yang berisi notification dari dosen mengenai materi yang akan dibahas dalam pertemuan di kelas 'sungguhan'. Aplikasi ini juga terdapat fitur penugasan dengan deadline yang telah ditentukan oleh dosen guna membuat mahasiswa disiplin dalam ketepatan waktu mengumpulkan tugas. Karena aplikasi ini mempunyai fitur Your Work untuk mengumpulkan tugas dan dosen dapat memberikan nilai secara langsung.

Selain pengumpulan tugas yang memberikan deadline untuk membuat mahasiswa disiplin dalam mengumpulkan tugas-tugasnya, penggunaan aplikasi ini juga dapat menumbuhkan komunikasi yang baik antara dosen dan para mahasiswanya. Tidak menutup kemungkinan bahwa dengan komunikasi yang baik akan membuat mahasiswa menjadi lebih aktif dalam mendalami materi yang diberikan oleh dosen. Selain pembelajaran tatap muka, aplikasi ini dapat digunakan sebagai forum diskusi kelas. Sebagai contoh, ketika dosen berhalangan hadir atau perkuliahan diliburkan, maka baik materi pembelajaran maupun tugas yang semestinya diberikan pada hari itu tetap dapat berjalan dengan forum diskusi yang sudah disediakan oleh aplikasi ini.

\section{Strategi Pembelajaran Bahasa Arab dengan Google Classroom}

\section{a. Materi Perkuliahan}

Pembelajaran berbasis daring khususnya google classroom untuk mata kuliah pendidikan bahasa Arab dinilai lebih efektif karena seluruh tujuan yang disajikan oleh forum google dapat dinikmati secara maksimal oleh seluruh pengguna forum tersebut. Walaupun mahasiswa merasa enjoy dengan belajar bahasa Arab berbasis google classroom tetapi tidak semua mahasiswa akan faham dengan materi yang telah diunggah di aplikasi ini. Karena terdapat beberapa materi yang harus dijelaskan secara tatap muka untuk memfasihkan pelafalan mufradât bukan hanya dibahas fokus dengan visual pada teks saja.

Ada beberapa kendala yang dihadapi daalam pembelajaran bahasa Arab berbasis google classroom yaitu perangkat komputer yang kurang memadai dan koneksi internet yang kurang maksimal, sehingga dapat mengurangi kecermatan kinerja mahasiswa dan dosen.

Penggunaan teknologi internet telah memberikan konsep baru untuk saling bekerjasama dalam menggabungkan berbagai human resource, infrastruktur, dan kapital sehingga memungkinkan terciptanya budaya unlimited possibility. Penggabungan berbagai disiplin ilmu memberikan sebuah kemungkinan untuk membuat berbagai penemuan 
baru. Teknologi yang tepat akan meningkatkan sebuah value dari produk. Karena dalam produk yang baik akan meningkatkan loyalitas konsumen, konsumer yang lokal kelak akan menjadi salah satu media advertising yang efektif dengan menceritakan manfaat dari produk tersebut.

Dalam sistem pembelajaran berbasis google classroom, aplikasi ini membebaskan tenaga pengajar untuk memberikan materi pembelajaran yang akan di distribusikan untuk anak didiknya.

Dengan didukung 42 bahasa, google classroom dapat memberikan tenaga pengajar yang menggunakan aplikasi ini sebuah akses ke sistem manajemen konten yang memungkinkan tenaga pengajar dalam mem-posting update terbaru tentang materi maupun tugas dan pekerjaan kepada anak didiknya.

Mengenai pembelajaran Mata Kuliah Bahasa Arab yang menggunakan aplikasi google classroom, terdapat materi pembelajaran yang diterapkan di dalamnya yang membuat para mahasiswa yang ada di dalam kelas tersebut menjadi senang karena keefektifan yang diberikan oleh aplikasi ini.

Pembelajaran dimulai dengan penjelasan dosen mengenai rencana perkuliahan semester kepada para mahasiswa. Setelah para mahasiswa mengerti tentang hal-hal yang akan menjadi acuan pembelajaran Bahasa Arab selama satu semester, dosen membagi para mahasiswanya ke dalam beberapa kelompok yang terdiri dari tiga sampai empat mahasiswa. Setiap kelompok akan membuat makalahnya secara masingmasing.

Pada setiap pertemuan di setiap minggunya, kelompok yang sudah membuat makalah dan dijadwalkan untuk presentasi akan mempresentasikan ke depan kelas mengenai makalah yang telah dibuat. Biasanya, pemateri akan membacakan beberapa percakapan berbahasa Arab dan para mahasiswa lainnya mengucapkan ulang percakapan tersebut.

Selain pemateri yang akan membacakan percakapan berbahasa Arab, mereka juga menjelaskan sedikit mengenai fi'il. Contohnya seperti fi'il mâdhi dan fi'il mudhâri'. Setelah cukup, dosen akan mengambil alih kelas dan akan menjelaskan kepada para mahasiswanya tentang materi yang sudah disampaikan oleh kelompok yang sudah mempresentasikan materi tersebut sebelumnya.

Setelah dirasa para mahasiswa sudah mengenal tentang materi yang sudah dijelaskan dosen, dosen akan memanggil secara acak dua sampai tiga mahasiswa untuk maju ke depan dan menjawab soal-soal mengenai materi yang sudah dijelaskan tersebut.

Perkuliahan bahasa Arab menggunakan materi yang bersumber dari buku " $\mathrm{Al}$ 'Arabiyyah li al-'Alam” karangan Hasan ibn Hasan Asy-Syamrani. ${ }^{10}$ Perkuliahan bahasa Arab sebagai matakuliah universitas memiliki tujuan supaya mahasiswa menguasai kosakata Arab yang terkandung di dalam percakapan bahasa Arab sederhana.

${ }^{10}$ Hasan ibn Hasan Asy-Syamrani, Al-Arabiyyah li al-'Alam, (Riyadh: King Saud University, 2010). 
Sedangkan materi kaidah bahasa Arab (Nahwu dan Sharf) disusun dengan melihat kebutuhan mahasiswa program studi non-bahasa.

Materi percakapan yang digunakan dalam perkuliahan meliputi tema sebagai berikut: al-ta'âruf, Thâlib jadîd, al-usrah wa al-aqârib, al-tha'âm, al-manzil, al-madrasah, alhadîqah, al-lughah al-'Arabiyah, al-'amal, dan al-jaww. Sedangkan materi kaidah yang dibahas dalam perkuliahan meliputi: Isim-fi'il-huruf, fi'il mâdhi dan mudhâri', fi'il amr, man'ût na'at, mudhâf - mudhâf ilaih, jumlah ismiyah, dan jumlah fi'liyah, mubtada dan khabar, fi'il, fâ'il, dan maf'ûl bih, kâna wa akhwâtuhâ, serta Inna wa akhwâtuhâ.

\section{b. Metode Perkuliahan}

Metode yang digunakan dalam perkuliahan bahasa Arab dilakukan melalui diskusi yang dipimpin oleh sebuah kelompok presentasi yang telah dibagi di awal kontrak perkuliahan. Kelompok presentasi dibentuk dengan mempertimbangkan perbedaan latar belakang pendidikan setiap mahasiswa, sehingga di setiap kelompok dapat ditemukan mahasiswa lulusan pesantren, lulusan madrasah, dan lulusan sekolah. Model pembelajaran yang dikembangkan dalam perkuliahan pun dilakukan dalam bentuk model peer learning/peer teaching (pembelajaran dengan tutor sebaya. Sedangkan dosen memiliki tugas sebagai fasilitator apabila proses diskusi menemukan hambatan).

Setiap tugas kelompok yang akan dipresentasikan wajib diunggah melalui aplikasi google classroom selambat-lambatnya H-1 presentasi kelompok. Hal ini bertujuan agar mahasiswa lain dapat membaca terlebih dahulu makalah presentasi supaya di hari perkuliahan diskusi akan terasa aktif dan hidup. Selain itu, Ujian Tengah Semester dilakukan dalam bentuk tugas kelompok yang wajib diunggah juga melalui aplikasi google classroom dengan menggunakan batas akhir waktu unggah. Hal ini dapat melatih kedisiplinan mahasiswa dalam mengerjakan tugas kuliah.

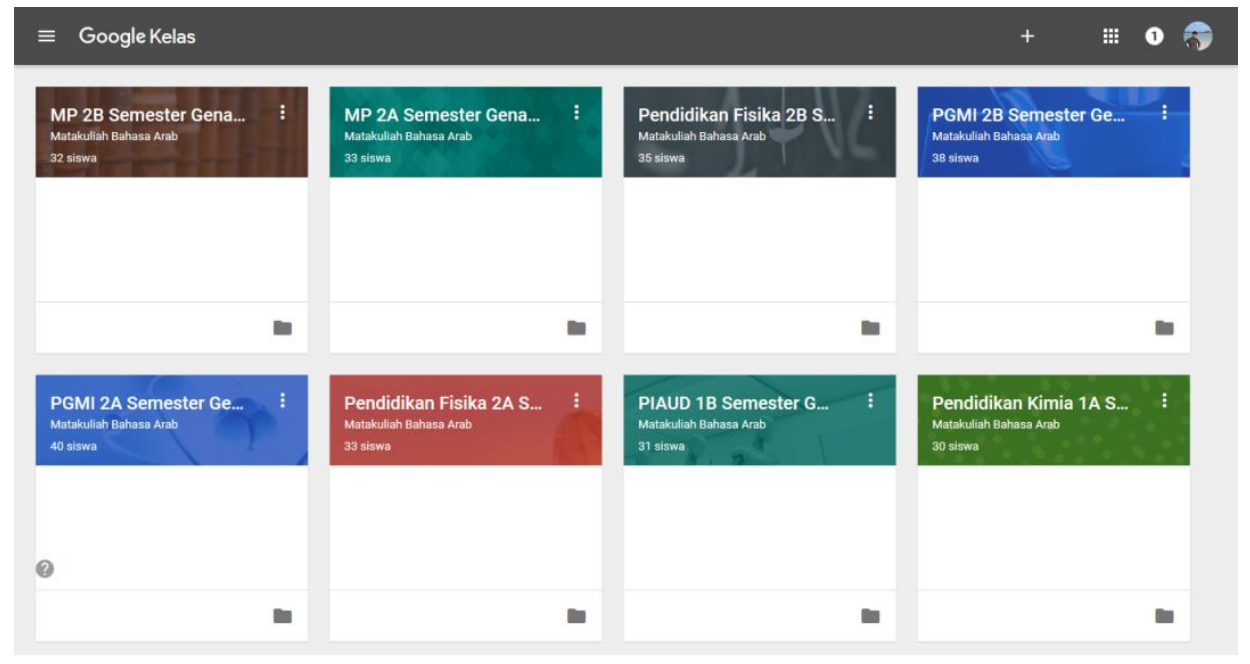

Gambar 3. Daftar Kelas di Google Classroom

Nilai formatif mahasiswa diperoleh dari kehadiran dan performansi mahasiswa dalam kegiatan diskusi. Selain itu, hasil tugas makalah presentasi dalam bentuk doc dan $p p t$ juga dijadikan pertimbangan untuk memberikan nilai formatif. Nilai kehadiran 
Arabiyât Jurnal Pendidikan Bahasa Arab dan Kebahasaaraban, 5 (1), 2018

dihitung menggunakan aplikasi AIS (Academic Information System) dengan dipadukan aplikasi Google Classroom. Sedangkan nilai Ujian Akhir Semester diperoleh melalui ujian akhir dalam bentuk Classroom Test untuk menguji pemahaman mahasiswa terhadap materi yang telah dipelajari.

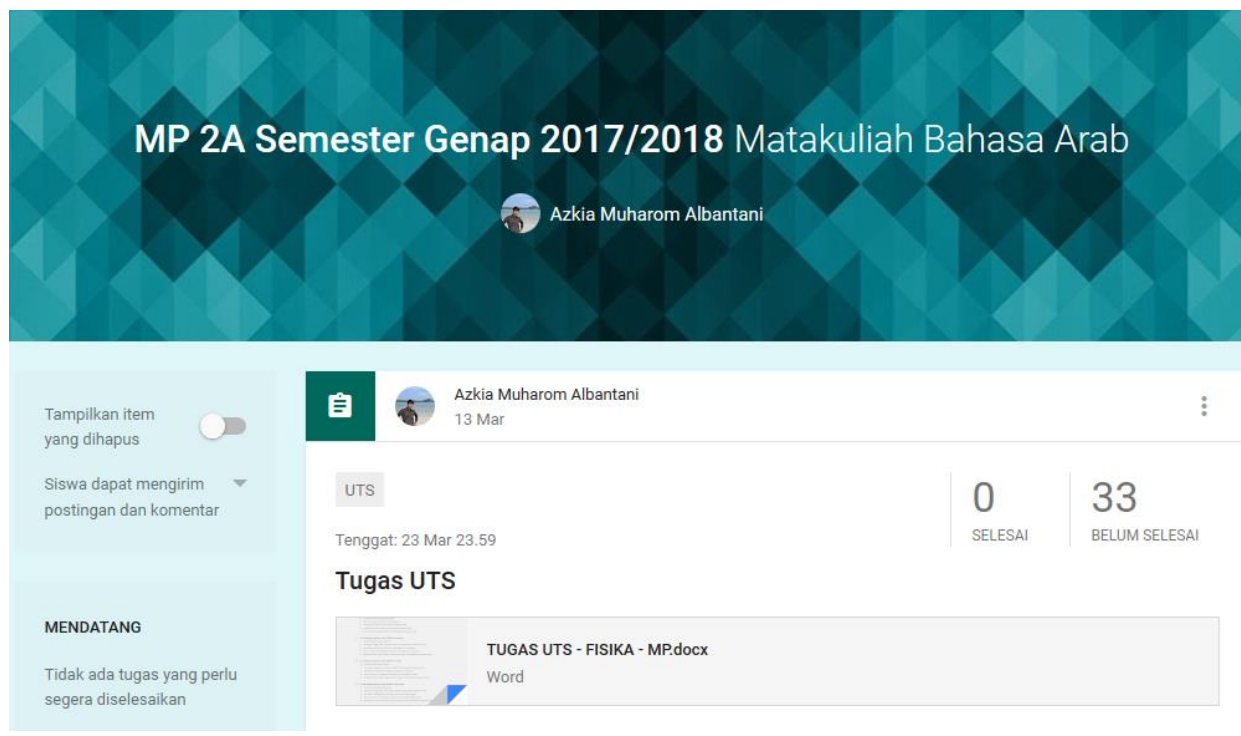

Gambar 4. Halaman Tugas di Google Classroom

Berbagai latihan juga dilakukan untuk mengukur sejauh mana pemahaman setiap mahasiswa setelah melakukan diskusi perkuliahan. Materi latihan meliputi berbagai kosakata yang terkandung dalam teks percakapan dan berbagai contohcontoh kaidah yang dipelajari.

Di dalam aplikasi ini terdapat beberapa metode yang bisa dimanfaatkan dalam pembelajaran bahasa Arab dikarenakan terdapat fitur-fitur yang dapat digunakan secara efektif, yaitu :

\section{a. Reuse post}

Digunakan untuk meretweet postingan yang sudah ada, dosen dapat menambahkan pertanyaan dan mengeditnya, juga dapat langsung dibagikan ke grup kelas yang akan dituju. Oleh karena itu, pembelajaran bahasa Arab berbasis google classroom ini sangatlah efektif jika digunakan dalam pembelajaran untuk menarik minat mahasiswa sehingga dapat mengaplikasikan pembelajaran bahasa Arab dalam kehidupan sehari-hari.

\section{b. Create question}

Create question adalah fitur yang dapat digunakan untuk memberikan pertanyaan kepada mahasiswa sehingga dapat lebih mudah mengakses pertanyaan dan mengunggah jawaban sesuai dengan due date yang telah ditentukan oleh dosen atau guru mata kuliah atau mata pelajaran yang bersangkutan dengan cara yang sangat efektif dan efisien dimana tidak menghamburkan kertas yang dapat mencemari lingkungan dan mengurangi populasi pohon dihutan, juga dapat memanage waktu 
sebaik mungkin. Selain itu juga penggunaan pembelajaran bahasa Arab berbasis google classroom dengan menggunakan fitur create question ini dapat mengefisiensi keberlangsungan perkuliahan tidak hanya bertatap muka untuk mengirim tugas.

\section{c. Create assignment}

Create assignment adalah fitur yang digunakan untuk dapat memberikan tugas, dan dapat melampirkan dalam bentuk file. Dengan fitur ini dosen dapat lebih mudah mengakses dan mengupload tugas yang akan diberikan kepada mahasiswa atau murid dengan menggunakan teknologi dan memanfaatkan teknologi berbasis google classroom ini dalam fitur create assignment. Selain itu juga, dosen dapat lebih terbuka terhadap teknologi tidak hanya menggunakan metode pembelajaran bahasa Arab secara tradisional dimana dosen atau guru menjadi satu-satunya objek yang aktif dalam keberlangsungan proses pembelajaran mengajar dalam aplikasi google classroom ini.

Selain itu, di pihak lain mahasiswa diuntungkan karena mereka hanya tinggal mengakses google classroom dan mengunduh tugas yang telah diberikan oleh dosen, serta mahasiswa tidak harus menulis atau mengetik soal yang diberikan oleh dosen, mereka hanya harus mengedit kemudian tinggal mengetik jawaban. Dosen harus memberikan due date pada fitur create assignment ini sehingga tujuannya agar mahasiswa dapat mengumpulkan sesuai dengan waktu yang telah ditentukan, dan agar mahasiswa tidak bersantai dan membuang waktu secara percuma. Secara tidak langsung fitur ini memberikan pembelajaran kepada siswa atau mahasiswa agar melaksanakan tugas tepat waktu atau mendisiplinkan waktu seefektif dan seefisien mungkin.

\section{d. Create announcement}

Create announcement adalah fitur yang digunakan untuk memberikan pengumuman. Dosen tidak harus menemui mahasiswa secara langsung melalui pembelajaran di kelas masing-masing, karena di jaman modern ini kita menggunakan teknologi yang serba canggih di mana dosen hanya menggunakan salah satu aplikasi yang telah dikembangkan oleh google yaitu aplikasi google classroom. Dosen hanya perlu memberi informasi atau pengumuman yang di post melalui aplikasi ini pada fitur create announcement dan diunggah pada masing-masing kelas sesuai dengan pengumuman yang akan disampaikan.

Metode adalah cara, yang merupakan alat untuk mencapai suatu tujuan. Makin baik metode itu, makin efektif pula pencapaian tujuan. Untuk menetapkan lebih dahulu apakah sebuah metode dapat disebut baik, diperlukan patokan yang bersumber dari beberapa faktor. Faktor utama yang menentukan adalah tujuan yang akan dicapai. Dengan memiliki pengertian secara umum mengenai sifat berbagai metode, baik seorang guru ataupun pengajar akan lebih mudah menetapkan metode manakah yang paling serasi untuk situasi dan kondisi pengajaran yang khusus. ${ }^{11}$

Pembelajaran bahasa Arab memerlukan perantara melalui media. Media Pembelajaran sendiri berasal dari bahasa latin medius yang secara harfiah berarti 'tengah', 'perantara' atau 'pengantar'. Dalam bahasa Arab, media adalah perantara

11 Winarno Surakhmad, Metodologi Pengajaran Nasional, (Bandung: Jemmars, 2004). h. 37 
atau pengantar pesan dari pengirim kepada penerima pesan. Dalam kegiatan belajar mengajar, sering pula pemakaian kata media pembelajaran atau (الوسائل التعليمية) digantikan dengan istilah-istilah seperti alat pandang dengar, bahkan pengajaran (instructional material), komunikasi pandang-dengar (Audio-visual Communication), pendidikan alat peraga pandang (Visual Education), teknologi pendidikan (Education Technology), alat peraga (وسائل الإيضاح) dan media penjelas (الوسائل التوضيحية).

Penggunaaan komputer sebagai media pembelajaran dalam Google Classroom secara umum mengikuti proses intruksional sebagai berikut :

1. Merencanakan, mengatur, dan mengorganisasikan dan menjadwalkan pengajaran

Di dalam aplikasi ini telah direncanakan berbagai rencana pembelajaran untuk mencapai suatu tujuan pembelajaran bahasa Arab yang efektif dan efisien. Serta mengatur bagaimana perencanaan pembelajaran itu berlangsung. Mengatur perencanaan dalam google classroom di sini yaitu sebagai contoh, di awal kontrak perkuliahan telah disetujui keberlangsungan pembelajaran sesuai kurikulum yang telah disetujui antara dosen dengan mahasiswa. Pengunggahan materi pun dilakukan secara bertahap dan urut sesuai dengan materi yang ada di silabus. Hal tersebut berarti mendeskripsikan bahwa aplikasi ini telah teratur. Google classroom juga berkaitan dengan pengorganisasian dan penjadwalan. Contohnya yaitu telah dipaparkan di atas bahwa pengunggahan materi oleh pemateri dalam hal ini yaitu mahasiswa, bukanlah suatu tugas individual yang harus dikerjakan secara perorangan melainkan secara berkelompok serta diupload secara terjadwal berarti di sini telah terlihat bahwa google classroom dapat mengorganisasikan dan menjadwalkan pengajaran bahasa Arab.

2. Mengevaluasi mahasiswa (test)

Google classroom dapat mengevaluasi siswa dari berbagai test. Contohnya, siswa atau mahasiswa akan mengikuti ujian melalui aplikasi ini, maksudnya adalah bahwa teks ujian tersebut sudah disediakan oleh dosen dalam google classroom, mahasiswa mengerjakannya lalu diupload di room ujian yang sudah tertera di aplikasi ini. Pengunggahan jawaban ujian biasanya sudah tertera pada room ujian tersebut, dan tidak boleh melebihi batas akhir pengunggahan jawaban ujian.

3. Mengumpulkan data mengenai mahasiswa

Di dalam google classroom terdapat data - data mahasiswa untuk mempermudah penilaian dari pengajar. Data-data tersebut meliputi biodata lengkap siswa, nilai - nilai hasil ujian, keaktifan siswa dalam berdiskusi melalui aplikasi ini. Apabila data data tersebut tidak dicantumkan dalam google classroom, maka dosen akan kesulitan untuk menilai bagaimana karakter dan keaktifan mahasiswa.

4. Melakukan analisis statistik mengenai data pembelajaran

Analisa statistik dalam google classroom ini bertujuan tidak jauh berbeda dengan tujuan pengumpulan data siswa melalui aplikasi ini. Yakni bertujuan untuk membuat

12 Azhar Arsyad, Media Pembelajaran, (Jakarta: Rajawali Pers, 2014). Cet.17, 3-6 
penilaian terhadap mahasiswa. Bagaimana keaktifannya di dalam forum berdiskusi di google classroom. Apakah mahasiswa tersebut selalu aktif atau hanya aktif di awal diskusi saja. Karena itu, harus dianalisis statistiknya. Apakah semakin berkembang keaktifan mahasiswa tersebut, atau semakin menurun tingkat keaktifannya.

5. Membuat catatan perkembangan pembelajaran kelompok atau perorangan

Catatan perkembangan pembelajaran kelompok atau perorangan dalam aplikasi ini penting juga yaitu perkembangan perorangan terutama dalam kelompoknya. Di sini akan terlihat bagaimana pemecahan bahasa Arab yang dilakukan dalam kelompok, apakah individu bisa berdiskusi dengan kelompoknya atau seorang individu tersebut tidak bisa berdiskusi dengan kelompoknya secara baik.

Format penyajian pesan dan informasi dalam Computer-Assisted Instruction (CAI) terdiri atas turorial terprogram, tutorial intelejen, drill dan praktis dan simulasi. Tutorial terprogram adalah seperangkat tayangan baik statis maupun dinamis yang telah lebih dahulu diprogramkan. secara berurut, seperangkat kecil informasi ditanyangkan yang diikuti dengan pertanyaan. Jawaban siswa dianalisis oleh computer (dibandingkan dengan kemungkinan-kemungkinan jawaban yang telah diprogram oleh guru/perancang), dan berdasarkan hasil analisis itu umpan balik yang sesuai. Urutan linear dan urutan bercabang digunakan. Penetapan kapan bercabang dimaksudkan untuk penyajian materi pelajaran tambahan berdasarkan, hasil analisis perkembangan siswa setelah menyelesaikan beberapa latihan dan tugas. Semakin banyak alternative cabang yang tersedia, semakin luas program tersebut menyesuaikan dengan perbedaan individual siswa. Media tambahan biasanya digabungkan untuk format tutorial terprogram, seperti tugas-tugas bacaan berbasis cetak, kegiatan kelompok, percobaan laboratorium, kegiatan latihan, simulasi, dan interaktif dengan videodisk. Manfaat tutorial terprogram akan tampak jika menggunakan kemampuan teknologi komputer untuk bercabang dan interaktif

Tutorial intelejen berbeda dari tutorial terprogram karena jawaban komputer terhadap pernyataan mahasiswa dihasilkan oleh intelejensia artifisal, bukan jawabanjawaban yang terprogram yang terlebih dahulu disiapkan oleh perancang pelajaran. Dengan demikian, ada dialog dari waktu ke waktu antara mahasiswa dan komputer. Baik mahasiswa atau komputer dapat bertanya atau memberi jawaban. Drill and practice digunakan dengan asumsi bahwa suatu konsep, aturan atau kaidah, atau prosedur telah diajarkan kepada mahasiswa. Program ini menuntun mahasiswa dengan serangkaian contoh untuk meningkatkan kemahiran menggunakan keterampilan. Hal terpenting adalah menggunakan penguatan secara konstan terhadap jawaban yang benar. Komputer dengan sabar memberi latihan, sampai suatu konsep benar-benar dikuasai sebelum pindah kepada konsep yang lainnya. Ini merupakan salah satu kegiatan yang amat efektif apabila pembelajaran itu memerlukan pengulangan. Untuk mengembangkan keterampilan atau mengingat dan menghafal fakta atau informasi. Meskipun pernah mendapat kritikan tajam, formal drill and practice kini memperoleh kembali tempat dalam pembelajaran. Tugas atau perilaku kompleks sering kali memerlukan keterampilan yang harus secara otomatis dilakukan, terutama keterampilan yang dikerjakan dengan kecepatan dan ketepatan. Keterampilan seperti 
Ara6iyât Jurnal Pendidikan Bahasa Arab dan Kebahasaaraban, 5 (1), 2018

ini hanya dapat dikuasai dengan mempelajarinya melalui latihan yang ekstensif. Latihan ekstensif yang dapat memberikan hasil penguasaan otomatis adalah melalui format kegiatan drill and practice pada komputer.

Yang diterapkan dalam pembelajaran selama ini adalah menggunakan metode forum diskusi dan pengiriman dokumen di Google Classroom. Jadi, di dalam setiap kelas dibagikan ke dalam beberapa kelompok yang terdiri dari 3 sampai 4 orang. Setiap kelompok tersebut membuat makalah dengan materinya masing-masing yang telah ditentukan oleh dosen. Terdapat batas waktu yang untuk pengumpulan tugas presentasi di Google Classroom yang diberikan oleh dosen yaitu H-2 sebelum presentasi dan metode ini sesuai dengan pembelajaran teknologi berbasis Google Classroom.

Dengan diterapkannya metode seperti ini, apabila dosen tidak dapat hadir ke dalam kelas, para mahasiswa tetap bisa menerima materi dan berdiskusi di dalam kelas bersama kelompok-kelompok lainnya di dalam kelas. Hal ini juga dapat menghemat waktu bagi para mahasiswa dalam menerima materi pembelajaran. Metode ini juga sangat bermanfaat bagi mahasiswa dan dosen. Kami sangat bersyukur sekaligus bangga telah menjadi bagian dari pembelajaran dengan metode daring menggunakan aplikasi Google Classroom tersebut.

Beberapa mahasiswa memberikan komentar bahwa di masa depan nanti ketika mereka sudah lulus dan menjadi tenaga pengajar tentu ingin sekali menerapkan metode pembelajaran Google Classroom karena media pembelajaran ini telah memberikan warna baru dan memberikan kemajuan dalam dunia pendidikan Indonesia maupun di dunia pendidikan dunia.

Mengaplikasikan Google Classroom tentunya bukan suatu hal yang mudah bagi dosen yang tidak memiliki kemampuan di bidang teknologi informasi. Namun sesungguhnya mengaplikasikan Google Classroom dapat dipelajari dengan memperhatikan langkah-langkah yang akan kami jelaskan berikut:

1. Buka laman google lewat laman Morilla Firefox atau Google Chrome, lalu buka tautan Google Classroom.

2. Pastikan mahasiswa dan dosen telah memiliki akun Google Apps for Education. Karena jika tidak memiliki akun tersebut, mahasiswa dan dosen tidak dapat mengaplikasikan Google Classroom. Jika sudah, kunjungi situs classroom.google.com dan sign in. Jika dosen, klik tulisan dosen untuk membuat kelas dan jika mahasiswa, klik tulisan mahasiswa lalu bergabung dengan kelas yang sudah dibuat oleh dosen menggunakan kode yang telah diberikan oleh dosen.

3. Dosen dapat menambahkan mahasiswa secara langsung atau berbagi kode dengan kelasnya agar mahasiswa dapat bergabung. Untuk hal ini berarti dosen di dalam kelas "sungguhan" sudah memberitahukan kepada mahasiswa bahwa dosen akan menerapkan google classroom pada pembelajaran memberikan syarat kepada mahasiswa untuk mengaktifkan e-mail universitas dengan cara melihat AIS (Aplication and Informatin System). E-mail yang akan dipergunakan harus menggunakan nama lengkap dan tidak boleh menggunakan nama panggilan atau nama samaran. 
4. Dosen memberikan tugas mandiri kelompok dan individu atau melemparkan informasi mengenai diskusi melalui laman tugas atau laman diskusi yang tersedia di dalam google classroom. Tugas atau mandiri yang telah disampaikan otomatis akan disimpan kedalam folder google drive.

5. Selain memberikan tugas mandiri kelompok atau individu, Dosen juga dapat menyampaikan penggunaan atau informasi terkait dengan mata pelajaran yang diampuya oleh mahasiswa di kelas nyata pada laman Google Classroom tersebut.

6. Mahasiswa dapat bertanya kepada dosen ataupun kepada temannya di kelas terkait dengan informasi yang disampaikan dosen yang kurang dipahami.

Mahasiswa dapat melacak setiap tugas yang diberikan oleh dosen yang hampir mendekati deadline batas waktu pengumpulan di laman tugas, lalu memulai mengerjakannya cukup dengan sekali klik. Dosen dapat melihat dengan cepat siapa saja mahasiswa yang belum menyelesaikan tugas yang diberikannya serta memberikan nilai serta masukan-masukan lainnya kepada anak didiknya mengenai tugas yang sudah dikerjakan langsung di Google Classroom.

Peran dosen dalam pembelajaran bahasa Arab melalui google classroom bukan hanya tahu nama dan tahu untuk apa serta megapa digunakan, tetapi juga sampai pada tingkat bagaimana menggunakan media tersebut yaitu media google classroom. Dosen pastinya tidak perlu repot menjelaskan materi pembelajaran kepada mahasiswa, karena setiap materi pembelajaran sudah tertera dalam aplikasi ini. Mahasiswa lah yang dituntut untuk selalu aktif dalam berdiskusi di google classroom.

Dosen yang menggunakan teknologi dalam pembelajaran merupakan dosen yang bersikap modern. Cara mengajar, gaya, dan strategi mengajar yang dimiliki oleh dosen seringkali merupakan refleksi dari apa yang dilakukan oleh dosen terlebih dahulu. Dosen harus bersedia mengubah sikap dalam mengajar dengan tidak mengajar secara konvensional (secara adat kebiasaan). ${ }^{13}$

Dosen juga harus bersikap sebagai mahasiswa yang sama-sama sedang belajar. Karena dosen juga harus menempatkan mahasiswa sebagai subyek didik bukan sebagai dewasa kecil. Tetapi dalam hal ini dosen sama-sama mengayomi mahasiswa dan proses belajar bersama.

\section{Kelebihan Google Classroom dalam Pembelajaran Bahasa Arab}

a. Proses pengaturan yang cepat

Proses pengaturan ulang pada google classroom sangatlah cepat dan nyaman dibandingkan jika kita harus menginstall aplikasi penunjang sistem pembelajaran yang lain, ataupun jika harus mendaftar ke penyedia penunjang sistem pembelajaran tersebut. Dengan menggunakan aplikasi ini, dosen tinggal mengakses aplikasi tersebut serta bisa memulai untuk membagikan tugas tugas serta bahan ajar. Google Clasroom

13 Azkia Muharom Albantani, Pembelajaran Bahasa Arab di UIN Syarif Hidayatullah Jakarta: Teori dan Praktik, (Ciputat: Cinta Buku Media, 2018), 241-260. 
lebih sederhana dan mudah untuk digunakan, sehingga ideal bagi dosen meskipun dengan tingkat pengalaman elearning yang beragam dan minim.

b. Sarana untuk membuat dan mengumpulkan tugas

Fitur pada aplikasi ini menggabungkan tiga layanan google yaitu : Google Docs, Gmail, dan Google Drive. Layanan tersebut akan memudahkan dosen untuk memberi tugas kepada mahasiswa, dan di sini mahasiswa juga bisa langsung mengumpulkan tugas ke folder dosen yang ada di Google Drive.

c. Hemat ruang dan waktu

Tugas dari dosen yang telah diterima oleh mahasiswa dapat langsung dikerjakan kapan saja dan dimana saja dengan syarat tidak melebihi waktu kadaluarsanya. Selain itu, penerapan aplikasi ini juga memudahkan dosen untuk memberikan nilai secara langsung dan meninggalkan pesan berkaitan dengan tugas mahasiswanya yang sifatnya pribadi (private). Sehingga dosen dan mahasiswa yang bersangkutan tahu tanpa harus bertemu dan bertatap muka secara langsung. Kita ketahui baik dosen maupun mahasiswa memiliki kesibukannya sendiri, dengan adanya aplikasi ini dapat mewakili pertemuan atau kontak langsung yang pada dasarnya sama saja ketika disampaikan secara lisan maupun disampaikan melalui Google Classroom. Dengan ini, kita mampu memperkecil kemungkinan terbuangnya waktu sia-sia.

d. Meningkatkan disiplin mahasiswa

Dari manfaat yang ketiga, maka lahirlah manfaat yang keempat ini. Dengan adanya batas waktu tertentu sebagai tanda akhir pengumpulan tugas, maka mahasiswa akan dituntut untuk lebih menghargai waktu walau hanya satu detik. Terlambat mengumpulkan tugas satu detik saja maka aplikasi ini akan memberikan informasi bahwa tugas yang dikumpulkan telah melewati batas waktu yang diberikan.

Dosen pun dapat melihat seberapa disiplin mahasiswanya, karena ketika batas waktu yang diberikan telah habis tidak mungkin dosen atau Google Classroom sendiri akan mentoleransi keterlambatan dan memperpanjang batas waktu pengumpulan kecuali dengan alasan yang dapat diterima dan masuk akal.

e. Meningkatkan kerjasama dan komunikasi kelas

Ketika menggunakan aplikasi ini, sangat mungkin untuk melakukan kolaborasi secara daring. Dosen dapat mengirimkan pemberitahuan kepada para mahasiswa untuk memulai sebuah diskusi sederhana secara daring atau memberitahu mahasiswa tentang kegiatan-kegiatan pembelajaran daring tertentu. Mahasiswa memiliki kesempatan untuk mendapat umpan balik dengan posting langsung ke aliran diskusi aplikasi ini. Dengan demikian, jika mereka membutuhkan bantuan ketika merasa kesulitan untuk memahami tugas yang diberikan atau ingin mempelajari lebih dalam tentang suatu materi atau pokok bahasan, mereka bisa mendapat masukan sekaligus berdiskusi di google classroom tersebut. Sehingga komunikasi akan terus berjalan walau tidak saling bertemu. 


\section{f. Penyimpanan data terpusat}

Dengan google classroom semua data baik dokumen maupun tugas tugas tersimpan dalam satu lokasi terpusat. Mahasiswa dapat menyimpan semua tugasnya dalam folder tertentu dan guru dapat menyimpan bahan ajar dan data nilai dapat dilihat dalam aplikasi. Dokumen tersebut tidak tercecer dan tersebar, mahasiswa dan dosen tidak perlu merasa khawatir tentang dokumen tugas atau penilaian yang akan hilang, karena semuanya telah tersimpan dalam google classroom.

g. Terjangkau, aman, dan nyaman

Terjangkau, karena mahasiswa dan dosen dapat memiliki aplikasi ini secara gratis tanpa dipungut biaya. Aman, karena tidak ada satu orang pun yang dapat mengakses akun aplikasi ini selain pemiliknua, kecuali jika kata kunci akun telah diketahui oleh orang lain. Nyaman, semua mahasiswa yang terdaftar di google classroom dapat berkomunikasi dengan dosen secara pribadi tanpa merasa malu dengan anggota yang lain. Karena tidak sedikit mahasiswa yang masih merasa canggung ketika berbicara di depan banyak orang.

h. Tetap teratur

Aplikasi ini akan secara otomatis membuat folder baru setiap ada tugas baru, baik di folder dosen maupun di folder mahasiswa yang bersangkutan.

\section{Kekurangan Google Classroom dalam Pembelajaran Bahasa Arab}

1. Buruknya jaringan wi-fi di kampus

Sebenarnya, UIN Jakarta sendiri memiliki banyak sekali jaringan internet atau wi-fi yang tersedia untuk para civitas akademik. Hanya saja hanya ada beberapa jaringan $w i-f i$ yang dapat diakses secara cuma-cuma oleh para mahasiswa. Jaringan wi-fi yang dimaksud adalah jaringan wi-fi dengan nama@mhs.uinjkt.ac.id. namun kecepatannya sangat lambat dan tidak menjangkau keseluruh penjuru kampus. Selain itu ada juga jaringan wi-fi yang tersedia di Fakultas Ilmu Tarbiyah dan Keguruan dengan nama jaringan@uinjkt.ac.id. namun jaringan tersebut tidak mencakup seluruh gedung di Fakultas Tarbiyah. Hanya tempat-tempat tertentu yang menjangkau jaringan wi-fi yang satu ini. Contohnya jaringan ini hanya cukup kencang di daerah Lobby Barat Fakultas Ilmu Tarbiyah dan Keguruan di mana area tersebut kurang nyaman bagi para mahasiswi untuk mengakses karena banyak sekali mahasiswa-mahasiswa yang nongkrong di tempat tersebut. Lambat atau buruknya koneksi jaringan wi-fi seperti ini sangat tidak mendukung dalam menerapkan aplikasi google classroom, karena koneksi yang buruk akan memperlambat dan mempersulit kegiatan belajar mengajar. Contoh kasus seperti itu adalah ketika kami akan mengunduh lampiran tugas yang diberikan oleh dosen, kami harus menunggu lama dan mencoba untuk me-refresh aplikasi ini berulang kali untuk mendapatkan lampiran tugas tersebut. Untuk kekurangan yang pertama ini karena masalah jaringan internet di sekitar kampus, jadi bukan mutlak kekurangan yang dimiliki dari situs aplikasi google classroom. 


\section{Tidak ada sistem notification dari aplikasi Google Classroom}

Hampir semua aplikasi sosial media yang diunduh di gawai atau di telepon selular melalui Play Store maupun App Store memberikan peringatan ketika adanya aktivitas tertentu dalam akun kita dengan sebuah pesan notifikasi berupa nada dering. Namun aplikasi google classroom belum memiliki fitur notifikasi. Hal ini membuat pengguna aplikasi tersebut tidak akan menyadari akan adanya tugas baru ataupun halhal baru mengenai perkuliahan yang diberikan oleh dosen tanpa membuka aplikasi terlebih dahulu.

\section{Hilang satu hilang seribu}

Google Classroom merupakan sebuah aplikasi yang dikembangkan oleh google yang selalu tersinkronisasi dengan google drive sebagai tempat untuk menyimpan file-file kita yang ada di dalam aplikasi ini. Di saat gawai yang digunakan untuk mengakses aplikasi ini hilang, maka akan hilang semua dokumen dan tugas-tugas yang sudah disimpan oleh google drive. Karena itu, perlu berhati-hati dalam membawa gawai ketika bepergian. Jika perlu, log out akun Google Classroom ketika sudah selesai menggunakannya guna mengantisipasi hal-hal yang tidak diinginkan.

4. Menuntut para mahasiswa untuk memiliki gawai yang canggih

Dalam menggunakan aplikasi ini, para mahasiswa yang terlibat harus mempunyai perangkat ponsel, laptop, atau tablet yang canggih guna mendukung dalam menggunakan aplikasi ini. Kalau ada mahasiswa yang tidak memiliki gawai yang mendukung, maka dengan terpaksa mahasiswa harus pergi ke warnet untuk mengakses aplikasi ini. Sebagai seorang dosen yang akan mempraktikkan aplikasi google classroom pada perkuliahan, ada baiknya mempertimbangkan lebih matang dalam menerapkan metode mengajar dengan aplikasi ini. Karena mungkin saja tidak semua mahasiswa yang diajar tidak memiliki gawai yang mendukung untuk aplikasi ini.

\section{Simpulan}

Dari uraian terdahulu, dapat disimpulkan bahwa pembelajaran bahasa Arab melalui google classroom memberi kemudahan bagi mahasiswa dan dosen dalam proses perkuliahan karena adanya jalinan komunikasi secara langsung dan jelas, terutama komunikasi mengenai tugas dan materi yang disampaikan. Aplikasi pembelajaran modern ini juga sangat menunjang dan membuka wawasan baru khususnya terhadap diri kami sendiri dan memotivasi para mahasiswa untuk mengerjakan dan mengumpulkan tugas dengan tepat waktu. Aplikasi google classroom membuat para mahasiswa dalam pembelajaran menyenangkan sehingga para mahasiswa merasa nyaman dalam mempelajari sesuatu sehingga belajar tidak lagi menjadi sebuah beban dan para mahasiswa berani untuk terus bereksplorasi dan bereksperimen terhadap pengetahuan yang dipelajarinya. Selain metode e-learning dalam pembelajaran berbasis google classroom yang telah memberikan kemudahan dan kelancaran dalam proses belajar mengajar bagi tenaga pengajar dan para mahasiswa, aplikasi google classroom juga dapat meningkatkan intensitas dalam komunikasi interaktif dengan peserta didik di luar jam belajar resmi. Metode ini juga memberikan keleluasaan pada dosen dalam memberikan 
Arabiyât Jurnal Pendidikan Bahasa Arab dan Kebahasaaraban, 5 (1), 2018

akses kepada mahasiswa untuk mendapatkan referensi ilmiah terkait dengan mata kuliah tersebut yang mungkin tidak didapat selama pertemuan tatap muka. Implikasinya di masa depan, para mahasiswa akan memiliki sebuah daya saing yang tinggi, mendalam dalam pengetahuan yang telah dipelajarinya dan tentunya memiliki prestasi nilai yang lebih baik.[

\section{DAFTAR RUJUKAN}

Albantani, Azkia Muharom. Ahmad Madkur, "Musyahadat Al Fidyu: Youtube-Based Teaching and Learning of Arabic As Foreign Language (AFL)", DIN AMIKA ILMU, Vol. 17 No. 2, 2017.

Albantani, Azkia Muharom. Pembelajaran Bahasa Arab di UIN Syarif Hidayatullah Jakarta: Teori dan Praktik, Ciputat: Cinta Buku Media, 2018.

Arsyad, Azhar. Media Pembelajaran, Jakarta: Rajawali Pers, 2014, Cet.17.

Asnawi, Noordin. "Pengukuran Usability Aplikasi Google Classroom Sebagai Elearning Menggunakan USE Questionnaire (Studi Kasus: Prodi Sistem Informasi UNIPMA)", Research : Journal of Computer, information system, \& technology management, Vol. 1, No. 2, 2018

Darmawan, Deni. Teknologi Pembelajaran, Bandung: PT Remaja Rosdakarya, 2012.

Garczynski, Heather. "Tech Tools for Teachers, by Teachers: Google is at it Again! Google Classroom Changes the Face of Education", Wisconsin English Journal, Vol. 56, No. 2, 2014.

Gunawan, Fransiskus Ivan. Stefani Geima Sunarman. "Pengembangan Kelas Virtual dengan Google Classroom dalam Keterampilan Pemecahan Masalah Problem Solving) Topik Vektor Pada Siswa SMK untuk Mendukung Pembelajaran", Prosiding Seminar Nasional Etnomatnesia, 2018.

Hakim, Abdul Barir. "Efektifitas Penggunaan E-Learning Moodle, Google Classroom dan Edmodo”, I-STATEMENT, Volume 2 Nomor 1, Januari 2016.

Herma, Widya. "Google Classroom Ruang Kelas Dunia Maya”, http://widyaherma.com diakses pada 27 April 2017 Pukul 12.30 WIB.

Iswanto, Rahmat. "Pembelajaran Bahasa Arab dengan Pemanfaatan Teknologi", Arabiyatuna: Jurnal Bahasa Arab, Vol. 1, No. 2, 2017.

Pradana, Diemas Bagas Panca. Rina Harimurti. "Pengaruh Penerapan Tools Google Classroom pada Model Pembelajaran Project Based Learning terhadap Hasil Belajar Siswa”, Jurnal IT-Edu, Volume 02 Nomor 01 Tahun 2017.

Pratama, Dicky. \& Hendri Sopryadi, "Analisis Pengaruh Pemanfaatan Google Classroom terhadap Efisiensi pada STMIK XYZ”, Seminar Nasional Teknologi Informasi 2016.

Ritonga, Mahyudin. Alwis Nazir, Sri Wahyuni, "Pembelajaran Bahasa Arab Berbasis Teknologi Informasi dan Komunikasi di Kota Padang", Arabiyât : Jurnal Pendidikan Bahasa Arab dan Kebahasaaraban, 3, (1), 2016. 
Arabiyât Jurnal Pendidikan Bahasa Arab dan Kebahasaaraban, 5 (1), 2018

Sadiman, Arief S. dkk, Media Pendidikan: Pengertian, Pengembangan, dan Pemanfaatannya, Depok: Rajawali Pers, 2012.

Surakhmad, Winarno. Metodologi Pengajaran Nasional, Bandung: Jemmars, 2004.

asy-Syamrani, Hasan ibn Hasan. Al-'Arabiyyah li al-'Alam, Riyadh: King Saud University, 2010.

Wicaksono, Vicky Dwi. Putri Rachmadyanti, "Pembelajaran Blended Learning Melalui Google Classroom di Sekolah Dasar", Prosiding Seminar Nasional Pendidikan PGSD UMS \& HDPGSDI Wilayah Jawa, 2017. 